\title{
Self-esteem of physical education students: sex differences and relationships with intelligence
}

\author{
Monika Guszkowska ${ }^{A, C, D, E, F}$, Anna Kuk ${ }^{B, E, F}$, Adriana Zagórska ${ }^{B, F}$, Katarzyna Skwarek ${ }^{B, F}$ \\ Józef Piłsudski University of Physical Education, Warsaw, Poland
}

BACKGROUND

The aim of the study was to determine the level of self-esteem of physical education and sport students, its diversification according to sex, as well as relationships between self-esteem and the following variables: fluid intelligence, emotional intelligence, social intelligence, and academic performance.

\section{PARTICIPANTS AND PROCEDURE}

A total of 385 first-year undergraduates aged 18-26 years studying physical education and sport at the University of Physical Education in Warsaw participated in the study. The following research tools were used: the Multidimensional Self-Esteem Inventory, Raven's Standard Progressive Matrices Plus, the Emotional Intelligence Questionnaire, and the Social Competence Questionnaire. The average of marks obtained for all courses taken during the first year was adopted as an indicator of academic performance.

\section{RESULTS}

The obtained results attest to the high self-esteem of the firstyear students. Male students gave higher ratings for their body appearance and body functioning, personal power and likeability, self-control, and competence. They also indicated a higher level of global self-esteem and identity integration. The highest number of significant positive correlations connected self-esteem and emotional intelligence; slightly fewer correlations existed between self-esteem and social competence. The lowest number of significant relationships was established for fluid intelligence. Only one positive predictor of average evaluations was established in male students (self-control) and female students (competence).

\section{CONCLUSIONS}

The profile of self-esteem of physical education students demonstrates their high self-esteem, especially in areas related to their field of study. Some variations in the components of self-esteem of male and female students reflect the differences between sexes typical for the Polish adult population.

\section{KEY WORDS}

self-esteem; students; physical education; sex differences; intelligence

CORReSPonding AUthor - Prof. Monika Guszkowska, Józef Piłsudski University of Physical Education, 34 Marymoncka Str., 00-968 Warsaw, Poland, e-mail: mguszkowska@wp.pl

Authors' CONTRibution - A: Study design - B: Data collection - C: Statistical analysis - D: Data interpretation .

E: Manuscript preparation · F: Literature search · G: Funds collection

To Cite this ARTICLE - Guszkowska, M., Kuk, A., Zagórska, A., \& Skwarek, K. (2016). The self-esteem of physical edu-

cation students: sex differences and relationships with intelligence. Current Issues in Personality Psychology, 4(1), 50-57. RECEIVED 29.07.2015 · REVIEWED 29.08.2015 · ACCEPTED 03.10.2015 · PUBLISHED 09.11.2015 


\section{BACKGROUND}

The central and most elaborate part of personality viewed as a cognitive system is self-concept understood as a loosely organised set of beliefs about oneself, the totality of all attributes that the individual considers as his or her and himself or herself, and a relatively steady self-image. Judgements about self can be descriptive and evaluative. The appraisal of oneself can occur at different levels of granularity: from the assessment of the person's selected facets to general self-evaluation, which also happens to be defined as self-respect (Kofta \& Doliński, 2000).

According to Rosenberg (1989), self-esteem is either a positive or negative orientation towards oneself, a global self-evaluation. Individuals may ascribe different levels of importance to specific areas of their functioning; their evaluation will thus, to varying degrees, constitute global self-esteem.

Perceived as a trait relatively stable over time, high global self-esteem denotes a belief in self-worth as a human being who is not necessarily better than others whereas low self-esteem means dissatisfaction with oneself. With the baseline level of the trait undergoing slow and gradual changes, short-term fluctuations in self-esteem leave no permanent trace (Rosenberg, 1989).

According to Kernis (2003), self-esteem is an affective reaction of a person to oneself. It can be either affectively or intellectually saturated, considered as a relatively stable characteristic, or a current state whose essence lies in the pursuit for self-enhancement - the defence, maintenance, or reinforcement of a positive self-view. People with high self-esteem have better psychological disposition, more robust physical health, and greater life accomplishments (Solomon, Greenberg, \& Pyszczynski, 1991).

Self-esteem can work as a vicious circle: people with low self-esteem have a more pessimistic outlook on life and their chances for success, so they become discouraged from making effort, which diminishes their performance, thus reinforcing their sense of low self-worth. While people with high self-esteem have a positive self-image and clearly defined beliefs about themselves, people with low self-esteem possess neutral yet uncertain, variable, and incoherent value judgements (Wojciszke, 2002).

High self-esteem can also bring about negative effects. People with high but unstable self-esteem, who tend to feel unfairly treated by others if they do not share their positive evaluations, have the strongest propensity for aggressive behaviour and anger arousal (Kernis, Grannemann, \& Barcley, 1989). It was also found that people with exceedingly high self-esteem are often disliked by others and perceived as selfish individuals (Baumaister, 1995).
Changes in self-esteem occur throughout the lifespan (Robins \& Trzesniewski, 2005), mainly as a result of transitions in social roles, family relations, socioeconomic status, professional competence, etc.

Protecting against harmful effects of stressful experiences, high self-esteem serves as a 'buffer', having a positive impact on the adaptation of the individual (Leary, Tambor, Terdal, \& Down, 1999). It also enables individuals to cope with fear of social alienation (Leary, 1999; Baumeister \& Tice, 1990), serves to sustain a coherent image of the self, helps assiduously pursue goals, and develops a sense of control over the surrounding environment (Leary et al., 1999).

One of the differentiating factors of self-esteem is the sex of the individual. It exerts an influence on self-image - its contents and social interaction routines (Cross \& Markus, 2004). Kling, Hyde, Showers and Buswell (1999) conducted analyses of sex differences in self-esteem that indicated a higher level of self-esteem in male participants. Conversely, in the research conducted by Jenaabadi (2014), it was female participants who displayed higher self-esteem.

People with high self-esteem hold a positive selfview, believe they are successful in life, are self-confident, feel important and are positive about the future (O’Brien \& Epstein, 1988). People with high self-esteem are more persistent when taking action, even in the face of failure; they are ambitious and often take risk; and they self-regulate behaviour more efficiently when performing tasks. Conversely, people with low self-esteem are both cautious and uncertain anticipate failure, are less persistent when performing tasks, and manifest less adaptable self-regulated behaviours (Dandeneau \& Baldwin, 2004; Crocker \& Park, 2004).

People with high self-esteem view themselves as more talented, intelligent and popular compared to people with low self-esteem even if, in objective terms, there are no differences between them. Differences in self-view also make both groups vary according to their attitude toward success. People with high-esteem are interested in being successful; they assess the likelihood of success higher, and when they achieve it, they attribute it to their skills. Alternatively, people with low self-esteem would rather seek to avoid failures than be successful, attributing failures to lack of skill. This results in a reciprocal escalation of differences in the assessment of one's own capabilities between people with high and low self-esteem (O’Brien \& Epstein, 1988).

The theoretical concepts described above and the research findings both confirm significant regulatory functions of self-esteem and its crucial role in goal-oriented activities. The question that arises, then, is about the relationship between self-esteem and the achievements of an individual. These relationships appear to be relatively easy to investigate in students due to the existence of quantitative indi- 
cators of academic performance. Despite this, it was relatively rare for researchers to seek relationships between self-esteem and academic performance. The results of the study involving Iranian students and conducted by Hasanvand and Khaledian (2012) demonstrated positive relationships between global self-esteem and academic performance. Conversely, the review of studies by Baumeister, Campell, Krueger, and Vohs (2003) suggests that the family's socioeconomic status lies behind the relationships between self-esteem and academic performance, affecting both the performance and self-esteem. Other research demonstrates, however, that success, including academic success, leads to high self-esteem. Longitudinal studies by Trzesniewski et al. (2006) show that the level of self-esteem in adolescence allows for participants' economic success and health to be predicted after ten years. Jenaabadi (2014), on the other hand, argues that self-esteem and emotional intelligence have no impact on the scientific attainments of students. It appears, therefore, that the question of the relationship between self-esteem and academic performance is not unambiguously conclusive.

In addition, a question that arises is about the rationale behind the self-esteem in this group: Can it be traced to the level of intelligence? If we expand the conception of intelligence beyond the purely cognitive sphere, we can then pose a question about the relationships between fluid, emotional, and social intelligence and the self-esteem of students.

The aim of the study was to determine the level of self-esteem of physical education and sport students, its diversification according to gender, as well as the relationships between self-esteem and the following variables: fluid intelligence, emotional intelligence, social intelligence, and academic performance. Research on physical education students seems to be particularly interesting. It can be assumed that an important component of their overall self-esteem is a self-worth in the physical domain. Their academic achievements may be associated not only with academic intelligence, but also with the level of physical fitness.

\section{PARTICIPANTS AND PROCEDURE}

A total of 385 first-year undergraduates (237 male students and 148 female students) aged 18-26 years $(M=20.08, S D=1.06)$ participated in the self-esteem study. They began their bachelor studies in physical education (85\%) and sport (15\%) at the University of Physical Education in Warsaw between 2010 and 2012. Data regarding the average of all marks obtained during studies were collected for 292 students (176 male students and 116 female students); a total of 251 students (148 male students and 103 female students) participated in an intelligence test. Groups did not differ in terms of age and the male-female ratio.

In the study, the Polish adaptation by Fecenec (2008) of the Multidimensional Self-Esteem Inventory (MSEI) by O'Brien and Epstein (1988) was used. It consists of 116 items comprising 12 scales: global self-esteem, competence, lovability, likeability, self-control, personal power, moral self-approval, body appearance, body functioning, identity integration, and defensive self-enhancement. The psychometric properties of the questionnaire are satisfactory. The indicators of internal consistency in the relevant age group range from .64 (moral self-approval) to .88 (body functioning), whereas the indicators of absolute stability range from .73 (moral self-approval) to .96 (body functioning). The validity of the scale was confirmed by establishing the relationships between its results and tools measuring mood, temperament, anxiety, adjustment and stress-coping strategies.

The tools described below were used to examine particular types of intelligence.

Raven's Standard Progressive Matrices Plus SPM Plus (Jaworowska \& Szustrowa, 2010) is a test that consists of 60 tasks with an increasing level of difficulty and no limit for response time. The result of the test indicates reasoning ability viewed as a significant indicator of fluid intelligence (independent of experience). In the age group of 21-30 years, the test displays high internal consistency (.93) and absolute stability (.93), which proves its validity. Correlations with the results of other intelligence tests corroborated the validity of the test.

The Emotional Intelligence Questionnaire (INTE) by Jaworowska and Matczak (2001) consists of 33 questions. The reliability of the scale is satisfactory (Cronbach's $\alpha$ in the student group is .84). The validity of the Emotional Intelligence Questionnaire (INTE) is substantiated by the correlations between the results of the scale and the scores obtained on the questionnaires of personality, temperament and social competence as well as the differences between students in various fields of study.

The Social Competence Questionnaire (SCQ) by Matczak (2001) in the version for adolescents (pupils and students) consists of 90 statements, of which 60 are diagnostic items. The social competence aggregate was assumed to indicate social intelligence. The reliability of the tool is satisfactory (in the group of students, Cronbach's $\alpha$ ranges from .76 to .89, whereas the coefficients of internal stability assume values from .71 to .85). The validity of the tool was substantiated by correlating its scores with the results of selected questionnaires measuring temperament and personality, as well as with intelligence tests.

The level of academic performance was established based on the average of marks obtained for all courses in the first year of study by those students who qualified for the second year. 


\section{RESULTS}

Table 1 presents three-level distributions of MSEI sten results in the entire group of subjects: low scores indicate low intensity of the characteristic under study (stens 1-4), average scores prove moderate intensity of the characteristic (stens 5-6), and high scores (stens 7-10) show high intensity of the characteristic.

These data corroborate high self-esteem of the first-year students at the University of Physical Education in Warsaw. People achieving high scores in all domains of self-esteem except lovability constituted the largest group. This group was the largest with regards to body functioning, personal power, and moral self-approval. More than half of the study participants highly rated their fitness, physical capacity and health, people management and influencing skills as well as the consistency between cherished values and their own behaviour. High global self-esteem, evaluation of one's own skills and efficacy, and physical attractiveness were reported in nearly half of the subjects. Only in the scale of lovability did the students most often achieve average results that testify to moderate self-esteem in the sphere of intimate relations with other people. The number of students presenting a strong and moderate sense of self-coherence was similar. Seeing that more than half of the subjects scored low on the scale of defensive self-enhancement, it could be assumed that the results of the study were only to a minor degree distorted by a strong need for social approval and acceptance.

Table 2 presents the arithmetic means and standard deviations of results obtained by female and male students in particular scales of the MSEI ques- tionnaire and the results of the single factor analysis of variance applied to establish differences between female and male students.

Significant differences were observed in eight out of eleven scales, with body appearance and identity integration demonstrating the most pronounced variations. Male students scored higher in all cases, giving better ratings for their body appearance and body function, personal power and likeability as well as their capacity for self-control and competence. They displayed higher global self-esteem and identity integration. No significant differences were observed only for lovability and acceptance, the evaluation of consistency between values and actual behaviour, and the tendency to defensive self-enhancement.

Table 3 presents Pearson's correlation coefficients illustrating the relationships between the domains of self-esteem and emotional intelligence, social intelligence, fluid intelligence, and academic performance. The dimensions of self-esteem (with the exception of moral self-approval) correlated most strongly with emotional intelligence, which may indicate that whenever substantial emotional intelligence occurs, it is accompanied by high self-esteem. The relationship between emotional intelligence and defensive self-enhancement suggests that scores on the Emotional Intelligence Questionnaire (INTE) may be affected by the propensity to present oneself in a more favourable light.

Directly proportional relationships linked self-esteem and social competence. They were particularly strong in the case of the self-assessments of personal power and likeability, namely the components of self-esteem that refer to relationships with other people. Lovability correlated with social competence. Social competence was also related to the self-eval-

Table 1

The three-level distribution of sten scores in the Multidimensional Self-Esteem Inventory (MSEI) as a percentage of the sample

\begin{tabular}{lccc}
\hline Self-esteem domain & $\begin{array}{c}\text { Low results } \\
(1-4 \text { sten })\end{array}$ & $\begin{array}{c}\text { Average results } \\
(5-6 \text { sten })\end{array}$ & $\begin{array}{c}\text { High results } \\
(7-10 \text { sten })\end{array}$ \\
\hline Global self-esteem & 28.90 & 22.90 & 48.20 \\
Competence & 20.30 & 33.90 & 45.80 \\
Lovability & 24.40 & 40.90 & 34.70 \\
Likeability & 25.40 & 36.80 & 37.80 \\
Personal power & 18.30 & 23.90 & 57.80 \\
Self-control & 33.90 & 30.60 & 35.50 \\
Moral self-approval & 25.00 & 24.70 & 50.30 \\
Body appearance & 25.20 & 31.10 & 43.70 \\
Body functioning & 8.20 & 23.20 & 68.60 \\
Identity integration & 27.80 & 34.80 & 37.40 \\
Defensive self-enhancement & 53.00 & 31.90 & 15.10 \\
\hline
\end{tabular}


Table 2

Means and standard deviations for scores on the MSEI as a function of gender

\begin{tabular}{lccccc}
\hline Self-esteem domain & \multicolumn{2}{c}{ Group } & $F$ & $p$ & $\eta^{2}$ \\
\cline { 2 - 4 } & Men & Women & & & \\
\hline Global self-esteem & $33.92(5.79)$ & $30.82(6.97)$ & 20.43 & $<.001$ & .05 \\
Competence & $36.34(4.96)$ & $33.82(6.66)$ & 15.71 & $<.001$ & .04 \\
Lovability & $36.89(6.11)$ & $36.42(6.94)$ & & n.s. & .03 \\
Likeability & $35.95(5.32)$ & $33.86(6.05)$ & 12.69 & $<.001$ & .05 \\
Personal power & $35.27(5.12)$ & $32.53(6.19)$ & 19.92 & $<.001$ & .05 \\
Self-control & $34.21(5.58)$ & $31.51(6.22)$ & 18.63 & $<.001$ & n.s. \\
Moral self-approval & $38.15(5.48)$ & $38.64(6.14)$ & & $<.001$ & .08 \\
Body appearance & $35.25(5.80)$ & $31.28(7.55)$ & 32.16 & $<.001$ \\
Body functioning & $40.83(5.67)$ & $37.59(6.36)$ & 22.32 & $<.001$ & .06 \\
Identity integration & $34.33(6.04)$ & $30.70(6.75)$ & 25.32 & $<.001$ & .06 \\
Defensive self-enhancement & $46.79(8.46)$ & $47.67(9.34)$ & & n.s. & \\
\hline
\end{tabular}

Table 3

Correlations between self-esteem, intelligence and academic performance (Pearson's $r$ coefficient)

\begin{tabular}{lcccc}
\hline Self-esteem domain & $\begin{array}{c}\text { Emotional } \\
\text { intelligence }\end{array}$ & $\begin{array}{c}\text { Social } \\
\text { competence }\end{array}$ & $\begin{array}{c}\text { Fluid } \\
\text { intelligence }\end{array}$ & $\begin{array}{c}\text { Academic } \\
\text { performance }\end{array}$ \\
\hline Global self-esteem & $.225^{* * *}$ & $.266^{* * *}$ & .038 & .035 \\
Competence & $.221^{* * *}$ & .135 & $.177^{* * *}$ & .113 \\
Lovability & $.172^{*}$ & $.190^{* * *}$ & $.136^{*}$ & .045 \\
Likeability & $.280^{* * *}$ & $.308^{* * *}$ & .054 & -.055 \\
Personal power & $.248^{* * *}$ & $.353^{* * *}$ & .107 & .005 \\
Self-control & $.152^{*}$ & $.172^{*}$ & .089 & $.128^{*}$ \\
Moral self-approval & .094 & -.009 & .021 & $.159^{* * *}$ \\
Body appearance & $.206^{* * *}$ & $.249^{* * *}$ & -.040 & -.073 \\
Body functioning & $.240^{* * *}$ & .125 & .082 & .066 \\
Identity integration & $.208^{* * *}$ & $.209^{* * *}$ & $.127^{*}$ & $.122^{*}$ \\
Defensive self-enhancement & $.188^{* * *}$ & .128 & .011 & -.008 \\
\hline Note.***$<<.001{ }^{*} p<.05$ & & & &
\end{tabular}

uation of body appearance and the capacity for self-control.

The lowest number of significant relationships was established for fluid intelligence. The score on the SPM test correlated positively with the self-evaluation of competence, lovability, and identity integration.

Academic performance correlated solely with the self-assessment of the consistency between cherished values, behaviour and self-control, as well as with the sense of coherence and self-esteem (identity integration).
Table 4 presents the results of the last step in stepwise regression conducted with the entire study group as well as separately for male and female students. The average of marks obtained during the first year of studies was introduced as a dependent variable, while all dimensions of self-esteem were introduced as factors. In the entire sample group, the only predictor of academic performance in the first year of studies was moral self-approval $(\beta=.16$, $p<.001)$, but it accounts for only $2 \%$ of the variability $\left(R^{2}=.02\right)$. Having included an additional factor - gender - we gained three predictors that explained 
nearly $13 \%$ of the variability of the average of marks. Better self-evaluations should be expected in female participants and people who rate their capacity for self-control and body functioning higher.

Only one predictor of average self-evaluation was established in male students (self-control) and female students (competence). Each of them explains about $5 \%$ of the variability of the average of marks.

\section{DISCUSSION}

The results of the study indicate high self-esteem of first-year students studying physical education and sport at the Józef Piłsudski University of Physical Educations in Warsaw. A particularly sizeable proportion of high scores was reported for self-evaluation of fitness and physical capacity (body functioning), people management skills (personal power), self-efficacy (competence), and physical attractiveness. In addition, the students rated highly the consistency between behaviour and cherished values. Only lovability self-evaluation was most often maintained at an average level.

It appears that the spheres where the students appraise themselves particularly highly are consistent with abilities and skills sought after by coaches and teachers of physical education. Perhaps high self-esteem in these spheres constituted one of the reasons for them to choose physical education and sport as a field of study. Low tendency to defensive self-enhancement supports the conclusion that the above-described results were not distorted by the subjects and their readiness to either protect or enhance their self-image.

Male students participating in our study rated higher their body appearance and body functioning, personal power and likeability, as well as their capacity for self-control and competence. They also displayed higher global self-esteem and identity integration. In none of the scales did female students score higher than male students. This allows us to conclude that in the group of physical education and sport students under study, it was male students who manifested higher self-esteem. The results of previous studies are equivocal in this respect. They reported higher self-esteem in male participants (Kling et al., 1999) as well as in the population of Polish adolescents aged 19-24 years (Dzwonkowska, Lachowicz-Tabaczek, \& Łaguna, 2008) and female participants (Jenaabadi, 2014). In the study about self-esteem that examined Polish students of physical education using the Fitts' Tennessee Self-Concept Scale (TSCS), higher scores were reported in female students (Brojek, 2012). Therefore, these issues require further research. Discrepancies may partially stem from the type of measuring instruments used. This interpretation is corroborated by the fact that in
Table 4

Self-esteem components as predictors of the average of marks obtained during studies (stepwise regression analyses)

\begin{tabular}{lcll}
\hline Group & Predictor & $\beta$ & $R^{2}$ \\
\hline & Step 1 & & \\
& Gender & $.30^{* * *}$ & .09 \\
& Step 2 & & \\
All & Gender & $.34^{* * *}$ & .12 \\
students & Self-control & $.19^{* *}$ & \\
& Step 3 & & \\
& Gender & $.36^{* * *}$ & .13 \\
& Self-control & $.16^{* *}$ & \\
Body functioning & $.12^{*}$ & \\
Men & Step 1 & $.24^{* * *}$ & .05 \\
Women & Self-control & & \\
& Step 1 & $.24^{* *}$ & .05 \\
\hline Note ${ }^{* * *} p<.001 *^{* *} p<.01{ }^{*} p<.05$ &
\end{tabular}

the course of normalisation studies of the Polish version of the MSEI scale, male participants aged 20-64 years reported higher self-evaluation of competence, personal power, body appearance, body functioning and identity integration - in other words, in five out of seven scales where significant differences were recorded in our study. It can be concluded that part of the observed variations in research targeting students reflects the differences between sexes typical for the adult Polish population.

Compared to their fellow male students, female students studying physical education and sport "additionally" rated lower their personal power, perseverance and self-discipline. Other data, not presented in this paper, suggest that female participants exhibit lower levels of social competence when exposed to social situations requiring assertiveness, which is consistent with the direction of differences in the MSEI's likeability scale. Neither male nor female students vary in conscientiousness measured with the NEO-FFI Inventory. It suggests that female students tend to underestimate their perseverance and self-discipline. Future studies should seek the reasons behind these differences.

Although self-esteem components show strong links to emotional and social intelligence, decidedly fewer relationships are reported for fluid intelligence. In a review of the subject literature, no studies were found that investigated relationships between self-esteem components and various types of intelligence. The research determined only positive correlations between global self-esteem and emotional intelligence (Hasanvand \& Khaledian, 2012; Jenaabadi, 2014) and social competence (Dzwonkowska et al., 2008), which corroborates the relationships observed 
in the study examining physical education students. Obviously, it is impossible in correlational studies to establish the causality of relationships. It is likely that a high level of social competence, namely the ability to cope with social situations acquired in the course of the social training, becomes the reason for a higher evaluation of one's own capabilities when dealing with other people. Conversely, a considerable actual ability to observe one's own and somebody else's feelings and emotions, to differentiate between them, and to use the information gathered in this way to reason and act causes individuals to evaluate higher their capacities in areas where emotional intelligence may prove significant. It cannot be ruled out, however, that the overall tendency for positive self-appraisal affects the answers given by the subjects in self-report questionnaires measuring levels of emotional and social intelligence.

The study examining physical education students at the University of Physical Education in Warsaw demonstrated few relationships between the components of self-esteem and fluid intelligence, limiting them to competence, lovability, and identity integration. Therefore, high fluid intelligence goes hand in hand with a high appraisal of one's own skills and efficiency at performing tasks as well as intimate contacts with other people and the sense of internal integration. Similar dependencies were established during normalisation studies for the MSEI scale (Fecenec, 2008).

It should be noted, however, that independent of sex, the studies observed additional significant correlations between intelligence quotient and self-esteem in the domains of personal power, body functioning, and moral self-approval which failed to manifest themselves when examining students. These differences may arise from the indicators of intelligence applied throughout the study. The study that examined students used the result of the Progressive Matrices test as the indicator of fluid intelligence understood as the capacity for education, whereas population studies used an intelligence quotient in the Wechsler Adult Intelligence Scale combining tests to measure fluid and crystallised intelligence.

Furthermore, in population studies the female group revealed positive correlations between general intelligence and the following self-esteem components: competence, lovability, likeability and body appearance (Fecenec, 2008). In our research, analyses were conducted together for both genders. Hence, it would be necessary to perform additional analyses in order to investigate whether self-esteem in the group of students is also more strongly related to intelligence in female students than in male students. These issues require further research, especially as the data regarding the relationships between self-esteem and intelligence vary significantly depending on both the measuring instruments used and the population under study (Baumeister et al., 2003).

\section{CONCLUSIONS}

To conclude, the self-esteem profile of physical education students testifies to high self-esteem, especially in areas closely linked to their field of study. Thus, it is fair to surmise that the self-evaluation of one's capabilities may constitute one of the criteria for the selection of this particular field of study. Some variations in the components of self-esteem of male and female students reflect the differences between sexes typical of the adult Polish population. The search for the origins of these differences should be preceded by population studies involving large groups of people at different ages to confirm their existence. It is fair to assume they are connected, at least partially, with the differences in educational influence exerted on boys and girls as well as gender stereotypes functioning in our society. These issues require further research.

\section{REFERENCES}

Baumaister, R. F. (1995). Self and identity: An introduction. In: A. Tesser (ed.), Advanced social psychology (pp. 51-97). Boston, MA: McGraw-Hill.

Baumaister, R. F., Campell, J. D., Krueger, J. I., \& Vohs, K. D. (2003). Does high self-esteem cause better performance, interpersonal success, happiness, or healthier lifestyles? Psychological Science in the Public Interest, 4, 1-44.

Baumaister, R. F., \& Tice, D. M. (1990). Anxiety and social exclusion. Journal of Social and Clinical Psychology, 9, 165-195.

Brojek, A. (2012). Struktura samooceny studentów wychowania fizycznego wybranych uczelni w Polsce [The structure of self-esteem among physical education students in the selected academies in Poland]. Polish Journal of Sport and Tourism, 19, 212-221.

Crocker, J., \& Park, L. E. (2004). The costly pursuit of self-esteem. Psychological Bulletin, 130, 392-414.

Cross, S. E., \& Markus, H. R. (2004). Płeć w myśleniu, przekonaniach i działaniu: podejście poznawcze [Gender in thinking, beliefs and actions: cognitive approach]. In: B. Wojciszke (ed.), Kobiety i mężczyźni: odmienne spojrzenia na różnice [Women and men: different views on the differences] (pp. 48-80). Gdańsk: GWP.

Dandeneau, S. D., \& Baldwin, M. (2004). The inhibition of socially rejecting information among people with high versus low self-esteem: The role of attention bias and the effects of bias reduction training. Journal of Social and Clinical Psychology, 23, 584-602.

Dzwonkowska, I., Lachowicz-Tabaczek, K., \& Łaguna, M. (2008). Samoocena i jej pomiar. Polska adaptacja skali SES M. Rosenberga. Podręcznik [Self-es- 
teem and its measurement. Polish adaptation of the SES scale by M. Rosenberg. Manual]. Warsaw: Pracownia Testów Psychologicznych PTP.

Fecenec, D. (2008). Wielowymiarowy Kwestionariusz Samooceny MSEI. Polska adaptacja. Podręcznik [The Multidimensional Self-Esteem Inventory MSEI. Polish adaptation. Manual]. Warsaw: Pracownia Testów Psychologicznych PTP.

Hasanvand, B., \& Khaledian, M. (2012). The relationship of emotional intelligence with self-esteem and academic progress. International Journal of Psychology and Behavioral Sciences, 2, 231-236.

Jaworowska, A., \& Matczak, A. (2001). Kwestionariusz Inteligencji Emocjonalnej INTE N. S. Schutte, J. M. Malouffa, L. E. Hall, D. J. Haggerty'ego, J. T. Cooper, C. J. Goldena, L. Dornheim. Podręcznik [Emotional Intelligence Questonnaire INTE by N. S. Schutte, J. M. Malouff, L. E. Hall, D. J. Haggerty, J. T. Cooper, C. J. Golden, L. Dornheim. Manual]. Warsaw: Pracownia Testów Psychologicznych PTP.

Jaworowska, A., \& Szutrowa, T. (2010). Test Matryc Ravena w wersji Standard TMS. Formy: Klasyczna, Równoległa, Plus. Polskie standaryzacje. Podręcznik (wyd. 2.) [Standard Raven's Progressive Matrices TMS. Forms: Classic, Parallel, Plus. Polish standarization. Manual (Vol. 2)]. Warsaw: Pracownia Testów Psychologicznych PTP.

Jenaabadi, H. (2014). Studying in the relation between emotional intelligence and self esteem with academic achievement. Procedia - Social and Behavioral Sciences, 114, 203-206. DOI: 10.1016/j. sbspro.2013.12.685

Kernis, M. H. (2003). Toward a conceptualization of optimal self-esteem. Psychological Inquiry, 14, 1-26.

Kernis, M. H., Grannemann, B. D., \& Barcley, L. C. (1989). Stability and level of self-esteem as predictors of anger arousal and hostility. Journal of Personality and Social Psychology, 56, 1013-1023.

Kling, K. C., Hydec, J. S., Showers, C. J., \& Buswell, B. N. (1999). Gender differences in self-esteem: A meta-analysis. Psychological Bulletin, 125, 470-500.

Kofta, M., \& Doliński, M. (2000). Poznawcze podejście do osobowości [Cognitive approach to personality]. In: J. Strelau (ed.), Psychologia. Podręcznik akademicki (wyd. 2) [Psychology. Academic Textbook (Vol. 2)] (pp. 561-600). Gdańsk: GWP.

Leary, M. R. (1999). Making sense of self-esteem. Current Directions in Psychological Science, 8, 32-35.

Leary, M. R., Tambor, E. S., Terdal, S. K., \& Downs, D. L. (1999). Self-esteem as an interpersonal monitor: The sociometer hypothesis. In: R. F. Baumeister (ed.), The self in social psychology (pp. 87-104). Philadelphia: Psychology Press.

Matczak, A. (2001). Kwestionariusz Kompetencji Spotecznych KKS. Podręcznik [The Social Competence Questionnaire KKS. Manual]. Warsaw: Pracownia Testów Psychologicznych PTP.
O'Brien, E. J., \& Epstein, S. (1988). MSEI: The Multidimensional Self-Esteem Inventory. Odessa, FL: Psychological Assessment Resources.

O’Brien, E. J., \& Epstein, S. (2008) Wielowymiarowy Kwestionariusz Samooceny. Podręcznik [The Multidimensional Self-Esteem Questionnaire. Manual]. Warsaw: Pracownia Testów Psychologicznych PTP.

Robins, R. W., \& Trzesniewski, K. H. (2005). Self-esteem development across the lifespan. Current Directions in Psychological Science, 14, 158-162.

Rosenberg, M. (1989). Society and adolescent self-image. Revised edition. Middletown: CT Wesleyan University Press.

Solomon, S., Greenberg, J., \& Pyszczynski, T. (1991). A terror management theory of social behavior: The psychological functions of self-esteem and cultural word-views. Advances in Experimental Social Psychology, 24, 91-159.

Trzesniewski, K. H., Donnellan, M. B., Moffitt, T. E., Robins, R. W., Poulton, R., \& Capi, A. (2006). Low self-esteem during adolescence predicts poor health, criminal behavior, and limited economic prospects during adulthood. Developmental Psychology, 42, 381-390.

Wojciszke, B. (2002). Człowiek wśród ludzi. Zarys psychologii spotecznej [A man among men. Outline of social psychology]. Warsaw: Wydawnictwo Naukowe Scholar. 